\title{
Adjustment, Motivation for Retention and Environmental Similarity toward Satisfaction among Expatriate Academics
}

\author{
Amir Parniana, Narges Hosseinia, Wong Shwu Fen ${ }^{a^{*}}$ \\ ${ }^{a}$ Faculty of Management, Universiti Teknologi Malaysia, 81300 UTM Johor Bahru, Johor, Malaysia \\ *Corresponding author: sfwong1984@hotmail.com
}

Article history

Received :4 April 2013

Received in revised form : 25 July 2013

Accepted :15 October 2013

\begin{abstract}
The purposes of this paper are to access the level of motivation, adjustment and environmental similarities among expatriate academics in a Malaysian university; and to analyze the influence of demography on satisfaction among expatriate academics in a Malaysian university. Limitation of this study is just focusing on one university of Malaysia. Survey questionnaire have been used to collect the data from randomly selected expatriate academics who currently working in Universiti Teknologi Malaysia (UTM). Only the Nationality is significant differences with satisfaction of expatriate academics in UTM. Expatriate academics are mostly motivated to remain by teaching context which has three items: rapport with departmental leadership, teaching opportunities, and nation building (ability to affect change). Fourteen items as motivation to remain which selected by $50 \%$ of the respondents are research opportunities, cost of living, reputation of the university, research funding, reputation of department, research/ lab facilities, international experience, professional development opportunities, geographic location of Malaysia, rapport with departmental leadership, teaching opportunities, nation building (ability to affect change), scholarly environment, and students. Research opportunities and cost of living identify as the most important factors of motivation. Majority of expatriate academics are able to adjust in host country. Expatriate academics are better in specific job responsibilities and supervisory responsibilities. "Everyday customs that must be followed" and "general living conditions (housing, etc.)" are similar from their home country.
\end{abstract}

Keywords: Expatriate academic; motivation for retention; personal adjustment; environmental similarities; satisfaction; Malaysian university

(C) 2013 Penerbit UTM Press. All rights reserved.

\subsection{INTRODUCTION}

For an instance, in Canada $40 \%$ of faculty are international or expatriate academics (Richardson et al., 2005). The ability of any organization to retain top people is fundamental for its growth and development (Collins, 2005), therefore faculty retention is an important issue for higher education institutions (Ambrose et al., 2005).

It was found that the poor international staffing decisions had estimated increased the cost from $\$ 200000$ to $\$ 1.2$ million in 1994 year of study by the National Foreign Trade Council (Ashamalla, 1998). In fact, the indirect costs are mostly lost in poor international staffing decisions and is hard to earn back the lost money in a short time period (Ashamalla \& Crocitto 1997; Daniels \& Insch 1998; Shilling, 1993). Indirect costs of expatriate failure for an organization could include strategic aims and goals not being achieved, negative impact on job productivity both in terms of the incumbent in the role and the expatriate's co-workers, and could even affect relations with the host-country nationals (Takeuchi et al., 2002). From the expatriate's perspective, the costs can be huge because it includes the negative psychological impact not only on the expatriate but also, potentially, on his/her spouse and family, lowered self-esteem and possibly negative consequences for future career goals (Black et al., 1999).

The primary objective of this research is to explore factors that influence retention of expatriate academics. To achieve this primary objective, it is compulsory to investigate the problems faced by expatriate academics and how it would affect the satisfaction of expatriate academics. Besides that, this research also seeks to scrutinize how demographics influence satisfaction of expatriate academics within the Malaysian context.

\subsection{LITERATURE REVIEW}

Globalization leads national academic to transform into international academic (Altbach \& Lewis, 1996). Contemporary higher education is fundamentally an international enterprise so the growing statistics of travel by international students and 
expatriate academics are highly common (Schermerhorn, 1999; Welch, 1997; Altbach \& Lewis, 1996). This development encourages many higher education institutions around the world to seek international academics or expatriate academics that can help to produce greater diversity internally among these institutions (Altbach, 1996).

Because of over-whelming challenges, it is influential of the expatriate's decision of remaining or let them reconsider staying in the host country (Aycan, 1997). Thus, cultural conflict will occur in this situation (Elashmawi \& Harris, 1993). Among the common challenges that expatriates noted during their stay in Malaysia, include the issues of the environmental awareness, local public services, restricted local media and cleanliness (Asma,1996). If expatriates had a high level of difficulty in adjusting to their new culture upon arrival, they would continue to have problems in adapting (Searle \& Ward, 1990; Ward \& Rana-Deuba 1999; Ward \& Kennedy, 1996).

Black et al. (1991) elaborated those 3 main dimensions of adjustment as work adjustment, general adjustment and interaction adjustment. Acculturation Curve has become the accepted representation of the cross cultural adjustment process. It is a four stage process that evolves over time which are euphoria, culture shock, acculturation and stable state. The Ucurve framework has been used by many researchers (Lysgaard 1955; Usunier, 1998; Black \& Mendenhall, 1990) to describe the expatriate cross-cultural adjustment process within a host culture. Seven points of expatriate adjustment process are unreality, fantasia, interest, acceptance of reality, experimentation, search, and integration. Language and cultural differences across countries also result in different degrees of jargons and this depends on the gap or cultural distance between the host country and the home country so the expatriate will need to adjust less or more to the host country (Mendenhall \& Oddou, 1991; Kogut \& Singh, 1988; Hofstede, 1980). The findings by Shaffer and Harrison (2001) state that adjustment is positively impacted by an expatriate's language skills and ability to re-establish a sense of self, and negatively by the spouse's feeling of problems in social behavior (Bauer \& Taylor, 2001).

Familiarity with the context of the host country may result in more realistic expectations of that culture and people, irrespective of any desire follow that culture (Usunier, 1998). These researches have shown that cultural distance is negatively correlated with the acculturation process (Stahl \& Cagliari, 2005; Bhaskar-Shrinivas et al., 2004; Black \& Stephens, 1989). Hofstede (1991) clarified that the construct distance of culture is commonly defined as the degree of differential dimensions of cultures.

Most commonly mentioned variables that influence academics' retention or leaving are organizational culture or climate (Callister, 2006; Piercy et al., 2005; Thompson, 2005); degree of fair treatment or procedural justice (Cohen-Charash \& Spector, 2001; Williams et al., 2002; Hassan \& Chandaran, 2005; Loi et al., 2006; Schoepp, 2010; Arif Hassan \& Junaidah Hashim, 2011); rapport with departmental leaders or leadership skills (Matier, 1990; Norman et al., 2006; Callister, 2006 ); collegiality (Ambrose et al., 2005; Barnes et al., 1998; Dee, 2004; Matier, 1990), the ability of expatriate and/or their family to adapt to new culture (Tung, 1981; Black \& Stephens, 1989; Sims \& Schraeder, 2004; Bhaskar-Shrinivas et al., 2004; HungWen, 2007). The other variables that may influence academics' retention or leaving are compensation and benefit (Weiler, 1985; Matier, 1990; Schoepp, 2010 ), quality of life (Schoepp, 2010) and personal fulfillment (Burke, 1988), administration (Johnsrud \& Rosser, 2002); demographics (Smart, 1990); individual status (Smart, 1990); job satisfaction and job involvement (Lee \& Mowday, 1987); Cross cultural and international experience (Richardson, 2008; Osland, 1990) along with nation building or global citizenship (Schoepp, 2010).

According to Social Exchange Theory (SET) (Blau, 1964) social behavior can be interpreted "as an exchange of goods, material and nonmaterial" (Homans, 1958, p. 597). Greatest satisfaction sources that enjoy in academics' works or job include the degree of autonomy (Tau \& Patitu, 1992) and the intellectual challenge (Magner, 1999). Most voluntary turnover conceptual models (Chiu \& Francesco, 2003; Birdseye \& Hill, 1995) assume that dissatisfaction of job or dissatisfaction is the employee turnover root cause. Birdseye and Hill (1995) noted that expatriates work in a new environment (such as different cultural, economic and political conditions) often face with both personal and job-related problems that can produce dissatisfaction and stress that may cause turnover finally.

\subsection{Satisfaction and Demographic}

Wan and Leightley (2006) found that higher levels of income, occupational position, and age were related to higher job satisfaction. In the study of Arif Hassan and Junaidah Hashim (2011), there were significant differences between nationals and expatriate staff and their perceptions towards organizational justice in terms of employment such as tenure, compensation, performance appraisals; promotion opportunities have been found in their research. Both tenure and age were negatively correlated with turnover intention (Arif Hassan \& Junaidah Hashim, 2011). Johnsrud and Heck (1994) found in their research that women were more likely to leave than men. After comparing non-doctoral and doctoral qualification in Schoepp's (2010) findings, the doctoral qualification (professors) viewed the components academic culture, academic resources and processes, and library as of greater motivations to leave rather than remain.

\subsection{Proposed Research Framework}

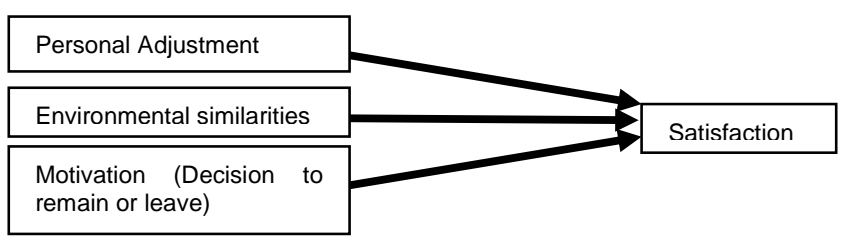

Figure 2.0 Proposed framework of this research

The hypotheses of this research are adjustment issues variable, environmental similarities variable, motivation for retention variable influence by demographics of expatriate academics toward their satisfaction.

\subsection{METHODOLOGY}

The quantitative research method will be adopted in this research. Quantitative method is a model for scientific research which is adopted by the majority researchers according to the requirement (Hammersley, 1993). Thus, survey questionnaire is the key instrument that will be used in this research.

The survey questionnaire is used to identify the problems faced by expatriate academics, how these factors related to 
satisfaction and how demographics influence satisfaction. The questionnaire has adopted from other developed questionnaires (Mark Fenton, 2010; Reynolds, 2010; Schoepp, 2010; Ahmadredza, 2011). Adjustment issues (section A), comparing with your home country (section B), satisfaction (section C) and demographics items have adopted from questionnaire of Reynolds (2010). Questions no.22 from satisfaction section has adopted from Reynolds (2010) and no.23 to 25 from satisfaction section have adopted from Ahmadredza's questionnaire (2011). Questions no. 26 to 72 from section D (Motivation to remain or leave) has adopted from Schoepp's (2010) questionnaire. Questions no. 73 and 74 of section D has adopted from the questionnaire of Mark Fenton (2010). For AHP questionnaire, all items have adopted based on Tsinidou et al. 's (2010) study.

The population size of expatriate academics in UTM was 165 members. Saiful (2011), a clinical researcher, who states that a sample size larger than 30 and less than 500 are appropriate for most research, adding that sub-samples also require at least 30 observations when applicable sample size. Moreover, Roscoe (1975) mentioned that sample sizes between 30 and 500 are appropriate random sampling method would be used as a rule of thumb. Thus, sample size of this research is 30 respondents because the expatriate academics have high mobility.

The software would be used for data analysis which was SPSS 16.0. SPSS software could do analysis such as factor analysis, reliability of the instrument, single mean T-test and independent sample test. Normality test would generate before conducting the inferential statistical analysis. The researcher assumed that the data was normal. Any abnormal data has been collected will cause the type of statistical change to nonparametric statistical techniques. Six major analyses would be conducted for normal data. Firstly, Cronbach Alpha scores would be generated to test the reliability of each of the constructs included in the survey instrument. Secondly, factor analysis would be conducted to test the significant relationships among the sub-variables of independent variables. Thirdly, independent sample tests would be used to compare satisfaction with two categories demographics.

\subsection{FINDINGS}

\subsection{Factor Analyses}

Based on Table 1, the top three of motivation to remain components were teaching context, scholar and living environment, and region and global perspective.

Table 1 Component names and mean scores for motivational components

\begin{tabular}{clc}
\hline Components & \multicolumn{1}{c}{ Name } & Mean \\
\hline $\mathbf{5}$ & Teaching context & 2.38 \\
$\mathbf{8}$ & Region \& global perspective & 2.53 \\
$\mathbf{7}$ & Scholar and living environment & 2.58 \\
$\mathbf{2}$ & Self-actualization opportunities & 2.77 \\
$\mathbf{6}$ & Academics' lifestyle & 2.79 \\
$\mathbf{3}$ & Adaptability in new environment & 2.80 \\
$\mathbf{1}$ & Organization culture & 2.84 \\
$\mathbf{4}$ & Compensation and benefits & 2.85 \\
\hline
\end{tabular}

As Table 2 presents, work adjustment variable had highest score of able to adjust, followed by cultural adjustment and interaction adjustment. All three component means showed that the expatriate academics of UTM were able to adjust in work, cultural and interaction adjustment. But they adjust better in work rather than cultural and interaction adjustment.

Table 2 Component names and mean scores of adjustment components

\begin{tabular}{clc}
\hline Components & \multicolumn{1}{c}{ Name } & Mean \\
\hline A3 & Work Adjustment & 4.39 \\
A1 & Cultural Adjustment & 3.93 \\
A2 & Interaction Adjustment & 3.74 \\
\hline
\end{tabular}

As Table 3 depicts, expatriate academics felt that the climate and lifestyle of Malaysia was same with their countries. But the general living, infrastructure and facilities component was a little different with their countries.

Table 3 Component names and mean scores of environmental similarities components

\begin{tabular}{llcc}
\hline Components & \multicolumn{1}{c}{ Name } & Mean \\
\hline ES 1 & Climate and lifestyle & 3.01 \\
ES 2 & $\begin{array}{l}\text { General } \\
\text { facilities }\end{array}$ & living, infrastructure and & 2.78 \\
\hline
\end{tabular}

Table 4 shows "research opportunities" item $($ mean= 2.2) in organizational culture component was a leading factor of motivation to remain among the expatriate academics. Next two following items mean below 2.30 were "cost of living" item in that region and global perspective and "rapport with departmental leadership" item in that teaching context.

The dichotomous scores generally reinforce the findings of the mean ranks, but they provide additional information about how often variables are actually cited as either a motivation to remain or leave. This score was calculated by assigning 1 for either "Strong Motivation to Remain" or "Motivation to Remain" for all factors below 3.0 and by assigning 1 for either "Strong Motivation to Leave" or "Motivation to Leave" for all factors above 3.0. Top two items in the dichotomous scores were "research opportunities" and "cost of living" item. At the end of the spectrum, there was an obvious concern from expatriate academics that they are not satisfied with opportunities elsewhere, the children's school and the spousal employment opportunities. 
Table 4 Descriptive statistics and single mean T-test of motivation (to remain or leave)

\begin{tabular}{|c|c|c|c|}
\hline Organization culture & Mean & $\begin{array}{c}\text { Std. } \\
\text { Deviati } \\
\text { on }\end{array}$ & Sig. \\
\hline Research opportunities & 2.20 & 1.126 & $0.001 *$ \\
\hline Reputation of the university & 2.30 & 0.915 & $0.000 *$ \\
\hline Research funding & 2.43 & 1.223 & $0.017^{*}$ \\
\hline Reputation of department & 2.43 & 0.858 & $0.001^{*}$ \\
\hline Teaching/ research load & 2.53 & 0.937 & $0.011^{*}$ \\
\hline \multicolumn{4}{|l|}{ Self-actualization opportunities } \\
\hline International experience & 2.47 & 1.306 & $0.033^{*}$ \\
\hline \multicolumn{4}{|c|}{ Adaptability in new environment } \\
\hline $\begin{array}{l}\text { Geographic location of } \\
\text { Malaysia }\end{array}$ & 2.30 & 1.264 & $0.005^{*}$ \\
\hline Malaysia Climate & 2.43 & 1.073 & $0.007 *$ \\
\hline $\begin{array}{l}\text { Voice in decision-making } \\
\text { processes }\end{array}$ & 2.67 & 0.884 & $0.048 *$ \\
\hline Children's school & 3.37 & 0.964 & $0.046^{*}$ \\
\hline \multicolumn{4}{|l|}{ Teaching context } \\
\hline $\begin{array}{l}\text { Rapport with departmental } \\
\text { leadership }\end{array}$ & 2.27 & 0.907 & $0.000 *$ \\
\hline Teaching opportunities & 2.40 & 0.77 & $0.000^{*}$ \\
\hline $\begin{array}{l}\text { Nation building (ability to } \\
\text { affect change) }\end{array}$ & 2.47 & 1.008 & $0.007 *$ \\
\hline \multicolumn{4}{|l|}{ Scholar and living environment } \\
\hline Collegiality & 2.47 & 0.73 & $0.000^{*}$ \\
\hline $\begin{array}{l}\text { Livability (traffic, groceries, } \\
\text { internet, etc.) }\end{array}$ & 2.50 & 1.009 & $0.011^{*}$ \\
\hline Scholarly environment & 2.53 & 1.008 & $0.017 *$ \\
\hline Semester length & 2.53 & 0.776 & $0.003^{*}$ \\
\hline \multicolumn{4}{|l|}{ Region and global perspective } \\
\hline Cost of living & 2.23 & 0.935 & $0.000 *$ \\
\hline Students & 2.33 & 1.028 & $0.001^{*}$ \\
\hline Geopolitical considerations & 2.60 & 0.968 & $0.031^{*}$ \\
\hline
\end{tabular}

Based on Table 5, five of seven items in cultural adjustment component were significant. All the items in the interaction adjustment and work adjustment were significant.

Table 5 Descriptive statistics and single mean score for adjustment items

\begin{tabular}{|l|c|c|c|}
\hline \multicolumn{1}{|c|}{ Adjustment } & Mean & $\begin{array}{c}\text { Std. } \\
\text { Deviatio } \\
\text { n }\end{array}$ & Sig. \\
\hline Cultural Adjustment & $\mathbf{3 . 9 3}$ & $\mathbf{0 . 7 6}$ & \\
\hline Living condition in general & 4.23 & 1.04 & $0.000^{*}$ \\
Housing condition & 4.10 & 1.09 & $0.000^{*}$ \\
$\begin{array}{l}\text { Food } \\
\text { Shopping }\end{array}$ & 4.03 & 1.00 & $0.000^{*}$ \\
Cost of living & 4.33 & 0.76 & $0.000^{*}$ \\
\hline Interaction Adjustment & 4.20 & 0.76 & $0.000^{*}$ \\
\hline $\begin{array}{l}\text { Socializing with Malaysian } \\
\text { Interacting with Malaysian } \\
\text { on a day-to-day basic }\end{array}$ & 3.63 & $\mathbf{0 . 6 0}$ & \\
$\begin{array}{l}\text { Interacting with Malaysian } \\
\text { outside of work }\end{array}$ & 3.87 & 0.97 & $0.012^{*}$ \\
\hline Work Adjustment jobecific & 3.73 & 0.94 & $0.000^{*}$ \\
\hline $\begin{array}{l}\text { My job } \\
\text { responsibilities }\end{array}$ & 4.53 & 0.63 & $0.000^{*}$ \\
$\begin{array}{l}\text { Performance standards \& } \\
\text { expectations of job }\end{array}$ & 4.20 & 0.71 & $0.000^{*}$ \\
$\begin{array}{l}\text { My supervisory } \\
\text { responsibilities }\end{array}$ & 4.43 & 0.68 & $0.000^{*}$ \\
\hline Overall & $\mathbf{4 . 0 2}$ & $\mathbf{0 . 6 3}$ & \\
\hline
\end{tabular}

Table 6 shows the mean was 2.89 (lower than neutral) in other words expatriate academics' home country were different with host country. There was no significant item found in climate and lifestyle component. However, there were 2 significant items found in general living, infrastructure and facilities component which were general living costs and transportation systems used in Malaysia.

Table 6 Descriptive statistics and single mean score for environmental similarities items

\begin{tabular}{|c|c|c|c|}
\hline $\begin{array}{l}\text { Environmental } \\
\text { Similarities }\end{array}$ & Mean & $\begin{array}{c}\text { Std. } \\
\text { Deviation }\end{array}$ & Sig. \\
\hline Climate and lifestyle & 3.01 & 0.97 & \\
\hline $\begin{array}{ll}\text { General } & \text { housing } \\
\text { conditions }\end{array}$ & 2.93 & 1.08 & 0.738 \\
\hline Climate & 2.77 & 1.43 & 0.379 \\
\hline $\begin{array}{l}\text { Available quality and } \\
\text { types of foods }\end{array}$ & 2.90 & 1.24 & 0.662 \\
\hline $\begin{array}{l}\text { Everyday customs that } \\
\text { must be followed }\end{array}$ & 3.43 & 1.17 & 0.051 \\
\hline $\begin{array}{lr}\text { General } & \text { living, } \\
\text { infrastructure } & \text { and } \\
\text { facilities } & \end{array}$ & 2.78 & 0.84 & \\
\hline General living costs & 2.53 & 1.11 & $0.028 *$ \\
\hline $\begin{array}{l}\text { Transportation systems } \\
\text { used in Malaysia }\end{array}$ & 2.47 & 1.11 & $0.013 *$ \\
\hline $\begin{array}{l}\text { Using health care } \\
\text { facilities }\end{array}$ & 2.80 & 1.06 & 0.312 \\
\hline $\begin{array}{l}\begin{array}{l}\text { General } \\
\text { conditions } \\
\text { etc.) }\end{array} \quad \begin{array}{l}\text { living } \\
\text { (housing, }\end{array}\end{array}$ & 3.30 & 1.18 & 0.174 \\
\hline Overall & 2.89 & 0.77 & \\
\hline
\end{tabular}

Table 7 shows that all items in satisfaction variable were significant. Expatriate academics at UTM are quite content.

Table 7 Descriptive statistics and mean score for satisfaction

\begin{tabular}{|c|c|c|c|}
\hline Satisfaction & Mean & $\begin{array}{l}\text { Std. } \\
\text { Deviat } \\
\text { ion }\end{array}$ & Sig. \\
\hline Overall degree of satisfaction & 4.23 & 0.57 & $0.000 *$ \\
\hline Satisfaction of service quality & 3.83 & 0.95 & $0.000 *$ \\
\hline Satisfaction of further studies & 3.70 & 0.95 & $0.000 *$ \\
\hline $\begin{array}{l}\text { Recommend to friends or } \\
\text { relatives }\end{array}$ & 3.80 & 0.96 & $0.000 *$ \\
\hline Overall & 3.89 & 0.76 & \\
\hline
\end{tabular}

One way Analysis of Variances (ANOVA) was used to identify whether the level of satisfaction differed among the nationality of expatriate academics. The analysis showed significant among the groups $(F=2.72, p<.05(0.03)$ see Table 4.18). As illustrated in Table 4.17, Indian respondents showed greater satisfaction $(M=4.63, \mathrm{SD}=0.75)$; Spanish respondents showed low satisfaction $(\mathrm{M}=1.75)$. 
Table 8 One way ANOVA for country of origin (nationality) and satisfaction

\begin{tabular}{lccccc}
\hline & $\begin{array}{c}\text { Sum of } \\
\text { Squares }\end{array}$ & df & $\begin{array}{c}\text { Mean } \\
\text { Square }\end{array}$ & F & Sig. \\
\hline $\begin{array}{l}\text { Between } \\
\text { Groups }\end{array}$ & 12.53 & 15.00 & 0.84 & 2.72 & 0.03 \\
$\begin{array}{l}\text { Within } \\
\text { Groups }\end{array}$ & 4.30 & 14.00 & 0.31 & & \\
& 16.84 & 29.00 & & \\
Total & & & & \\
\hline
\end{tabular}

\subsection{CONCLUSION}

After compared among the eight components of motivation for retention, it indicates that expatriate academics are mostly motivated to remain by teaching context which has three items: rapport with departmental leadership, teaching opportunities, and nation building (ability to affect change). Because of teaching context component has the lowest mean, which indicates highest motivation to remain, among all the components. All three items in teaching context component is related to Maslow's social needs. Most of time expatriate academics are social with their students and department leadership. Because of acceptance by group as human need, expatriate academics enjoy to have a rapport relationship with department leadership. They can be motivated by teaching opportunities and nation building because they feel that department and students need them. All sub-variables or items in this variable that mentioned above let expatriate academics are filled with the needs of social in campus small society. This result is similar with Matier (1990), Norman et al. (2006) and Callister (2006) results that rapport with departmental leadership is an important motivational tool. Schoepp (2010) also has mentioned that nation building is a important variable to motivate expatriate academic to remain.

The overall analysis of items which served as motivations (to remain or leave) is highly positive for the institutions and the country. Because among 47 items, 44 items of factors were identified via the mean scores as motivations to remain rather than to leave. It shows that majority of expatriate academics are quite content. The dichotomous scores identify fourteen items as motivation to remain. These items were selected by $50 \%$ of the respondents. These items are research opportunities, cost of living, reputation of the university, research funding, reputation of department, research/ lab facilities, international experience, professional development opportunities, geographic location of Malaysia, rapport with departmental leadership, teaching opportunities, nation building (ability to affect change), scholarly environment, and students. Research opportunities and cost of living identify as the most important factors of motivation. This result indicates that the UTM expatriate academics are motivated to remain because of research opportunities provided by UTM and cost of living in Malaysia.

Research opportunities represent the top motivational factor to retain the UTM expatriate academics. The need of research opportunities can explain through self-actualization need in Maslow's need hierarchy. Other factors which enhance motivation are lab facilities and research funding. This is because research opportunities, research facilities and funding are essential for advancement in academic field. That is why they are also motivated by the professional development opportunities. Another motivational factor is international experience which is in accordance with Maslows' selfactualization needs. They are motivated by international experiences factor which helps them become more professional in global perspective and fulfill the personal growth.

The second motivational factor of UTM expatriate academics is cost of living. They enjoy in Malaysia as cost of living is not high as compare with other countries, feel secure from economic perspective and fulfill all the physiological needs easily. Beside that, Geographic location of Malaysia is also a motivational factor. This is because Malaysia has a strategic location which is near to other countries like Indonesia, Singapore, Australia, India and Bangladesh.

The results of this study shows three factors of motivation to leave which are children's school, opportunities elsewhere, and spousal employment opportunities. Over two of three factors that mentioned above, which are opportunities elsewhere and spousal employment opportunity are related with Maslow's esteem needs. The UTM expatriate academics feel lack of opportunities elsewhere and their spouses get less employment opportunities. Main reason is the language barrier which is the main difficulty in finding job opportunities for foreigners. English is understandable within university campus and the languages spoken outside university are their local languages. The children's school factor is also playing a critical role in creating intentions to leave because it difficult to find good quality English school. Most of the schools are in Malay language which is national language of Malaysia. "Children's education" also had been identified by Jaeggi (2003) as one of the biggest source of dissatisfaction of expatriates in Malaysia.

The component with the highest mean is "compensation and benefit". It means that "compensation and benefit" is the least motivation factor for respondent to remain. It is easily understandable because normally the academics have higher job security as compare with other jobs so they have already fulfilled their primary needs (physiological and security needs).

Overall the level of motivation among expatriate academics in Malaysian university, UTM, is higher because more than half of the items shows motivation to remain and just three out of forty-seven items shows motivation to leave.

Majority of expatriate academics are able to adjust in host country. The result shows that adjustment in work is better than cultural and interaction adjustment which also supported by Black et al. (1991). Expatriate academics are less able to adjust in interaction adjustment just because of the language barrier in interacting with the local community. Half of respondents have been working more than 2 years; it shows that they maybe in the fourth phase of cultural adjustment, acculturation phase or stable state phase. After this phase, individuals will have developed a positive, neutral, or negative opinion toward host culture (Hofstede \& Hofstede, 2005). The positive opinion toward host culture of expatriates will let them continue to stay; for those who have neutral opinion toward host culture may or may not stay.

The one sample T-test shows that expatriate academics think about "everyday customs that must be followed" and "general living conditions (housing, etc.)" are similar from their home country. The result shows there is a minor difference between the host country and home country. However the environment is different but they can adjust for the new environment which has proven it in the result of adjustment. This result is similar with previous findings (Mendenhall \& Oddou, 1991; Kogut \& Singh, 1988; Hofstede, 1980). They mentioned language and cultural differences across countries also resulted in different degree of jargons and this depends on the gap or cultural distance between the host country and the 
home country. Hofstede (1991) identified four cultural values on which one culture can be differentiated from the other culture which are Power Distance, Collectivism vs. Individual, Masculine vs. Feminine, and Uncertainty Avoidance. Because of different culture of respondents cause they feel different between the home country and host country. The majority of respondents were from Indonesia, Bangladesh, India, Pakistan, British. The others came from Yemen, Australia, Spain, Iraq, Canada, Egypt, Afghanistan, Poland, Iran, Italy and Singapore.

According to Hofstede (1991) model, it shows that in Malaysia has high power distance index (larger gap between higher rank employee and lower rank one), high feminine index (higher feeling, cooperation and prefer working in group) and high collectivist index (press on group /masses achievement) whereas it has low uncertainty avoidance index (prefer unpredictability; achievement-oriented; desire to take risk; and have fewer adherences to hierarchies, procedures and rules). India is high on power distance, collectivist and masculinity and low on uncertainty avoidance index. Indonesia is high on power distance, collectivist, low on uncertainty avoidance and feminine country. Pakistan is strong on uncertainty avoidance and masculine country. There are some similarities among these countries in four dimensions of Hofstede's (1991) cultures differential degree model:

1 Malaysia, India, and Indonesia are large power distance, collectivist and weak uncertainty avoidance countries. The people in these countries have the larger gap between members who are higher rank employees/ employers and lower rank employees; prefer to work together, complete tasks as a whole and evaluate as masses achievement; prefer predictability, don't desire to take risk; and have more adherences hierarchies, procedures and rules.

2 Malaysia and Indonesia are feminine countries. It means these two countries are cooperative work group environment in business; believes in group achievements; and embody emotions within the business environment and uses them to help build interpersonal relationships.

The result of Environmental similarities components analysis shows that expatriate academics home country's climate and lifestyle was not same with climate and lifestyle of Malaysia. But the general living, infrastructure and facilities component was a somewhat similar. Ward and Rana-Deuba (2000), and Zakaria (2000) mentioned that in order to make their performance effective, expatriates make quickly adjustments in their lifestyles towards whatever challenges they face in a new culture.

Only the Nationality is significant differences with satisfaction of expatriate academics in UTM. Beside that gender, marital status, age category, highest degree earned, previous overseas work experience, and length of employment in UTM are not significant different with satisfaction of expatriate academics in UTM.

Indian respondents showed the greatest of satisfaction as compared with others; Spanish respondent showed the least satisfaction. According to the Hofstede's (1991) cultural model, India cultural values are similar with Malaysia cultural values but the Spain culture is different. From the power distance dimension, it is found that India has a difference of approximately 25 degree; whereas Spain has a difference of approximately 46 degree. Analysis of the collectivismIndividualism dimension; it shows that the two countries have almost same degree of difference with Malaysia. However from another two dimensions, it shows significant difference of degree among the India, Spain and Malaysia. According to uncertainty avoidance dimension, it shows approximately 50 degree distance with Malaysia, but the India just showed 4 degree (very small degree distance) with Malaysia. After the analysis of masculinity- femininity dimension, Spain has approximately distance of 8 degree from Malaysia; however India shows only 6 degree distance.

\section{Acknowledgement}

We are grateful for the UTM scholarship to Author 1 .

\section{References}

[1] Abraham H. Maslow. 1954. Motivation and Personality. 1st edition: 1954, 2nd edition: 1970, 3rd edition 1987.

[2] Ahmadredza Shekarchizadeh Esfahani. 2011. A Sequential MixedMethod Approach to Assess International Post Graduate Students' Perceptions of Service Quality. Doctor Philosophy, Universiti Teknologi Malaysia, Skudai.

[3] Altbach, P. G. and Lewis, L. S. 1996. The Academic Profession in International Perspective. In Altbach, P. G. 1996. The International Academic Profession Portraits of Fourteen Countries, Carnegie Foundation for the Advancement of Teaching, Princeton, MA. 3-48.

[4] Altbach, P. G. ed. 1996. The International Academic Profession Portraits of Fourteen

[5] Ambrose, S., Huston, T., and Norman, M. 2005. A Qualitative Method for Assessing.

[6] Ambrose, S., Huston, T., and Norman, M. 2005. A Qualitative Method for Assessing Faculty Satisfaction. Research in Higher Education. 46(7): 803-830.

[7] Arif Hassan and Junaidah Hashim. 2011. Role of Organizational Justice in Determining Work Outcomes of National and Expatriate Academic Staff in Malaysia. International Journal of Commerce and Management. 21(1): 82-93.

[8] Ashamalla, M. 1998. International Human Resource Management Practices: The Challenge of Expatriation. CR. 8(2):54-65.

[9] Ashamalla, M., \& Crocitto, M. 1997. Easing Entry and Beyond: Preparing Expatriates and Patriots for Foreign Assignment Success International Journal of Commerce \& Management. 7(2): 106-114.

[10] Asma, A. 1996, February 16. Delights, Puzzles And Irritations of Malaysian Culture.

[11] Aycan, Z., \& Kanungo, R. N. 1997. Current Issues and Future Challenges in Expatriate Management. In D.M. Saunders (Series Ed.) (Vol. Ed.). New Approaches to Employee Management. Greenwich, CT: JAI Press. 245-260.

[12] Barnes, L. B., Agago, M. O., and Coombs, W. T. 1998. Effects of JobRelated Stress on Faculty Intention to Leave Academia. Research in Higher Education. 39(4): 457-469.

[13] Bauer, T. and S. Taylor. 2001. A Globalized Conceptualization of Organizational Socialization. In N. Anderson, D.S. Ones, H.K. Sinangil, and C. Viswesvaran (Eds.). International Handbook of Work and Organizational Psychology. Volume 2, Sage Press.

[14] Bhaskar-Shrinivas, P., Harrison, D. A., Shaffer, M. A., \& Luk, D. M. 2004. What Have We Earned About Expatriate Adjustment? Answers Accumulated From 23 Years Of Research. RC Papers on CrossCultural Management. Retrieved May10, 2008, from http://net2.hkbu.edu.hk/ brc/CCMP200405.PDF.

[15] Birdseye, M. G., \& Hill, J. S. 1995. Individual, Organizational/Work and Environmental Influences on Expatriate Turnover Tendencies: An Empirical Study. Journal of International Business Studies. 26(4): 787-813. Retrieved from ABI/INFORM Global database.

[16] Black, J. and Mendenhall, M. 1990, The U-curve Adjustment Hypothesis Revisited: A Review and Theoretical Framework. Journal of International BusinessStudies. 2: 225-46.

[17] Black, J. S. \& Stephens, G. K. 1989. The Influence of the Spouse on American Expatriate Adjustment and Intent to Stay in Pacific Rim Overseas Assignments. Journal of Management. (15): 529-544.

[18] Black, J., Gregerson, H., Mendenhall, M. and Stroh, L. 1999. Globalizing People through International Assignments. AddisonWesley, Reading, MA.

[19] Blau, P. M. 1964. Exchange and Power in Social Life. Wiley, New York, NY.

[20] Burke, R. J. 1988. Some Antecedents and Consequences of WorkFamily Conflict. Journal of Social Behavior and Personality. 3: 287 
302.

[21] Callister, R. R. 2006. The Impact of Gender and Department Climate on Job Satisfaction and Intentions to Quit for Faculty in Science and Engineering Fields. The Journal of Technology Transfer. 31(3): 367375.

[22] Chiu, R. K. \& Anne Marie Francesco. 2003. Dispositional Traits and Turnover Intention: Examining the Mediating Role of Job Satisfaction and Affective Commitment. International Journal of Manpower. 24(3):284-298

[23] Cohen-Charash,Y. and Spector, P. E. 2001. The Role of Justice in Organizations: A Meta-Analysis. Organizational Behavior and Human Decision Processes. 86: 278-321.

[24] Collins, J. 2005. Good to Great and the Social Sector. Boulder, CO: Author. Countries', Carnegie Foundation for the Advancement of Teaching, Princeton, MA. 3-48.

[25] Daniels, J. D. and Insch, G. S. 1998. Why Are Early Departure Rates From Foreign Assignments Lower Than Historically Reported? Multinational Business Review. 6(1): 13-23.

[26] Dee, J. R. 2004. Turnover Intent in an Urban Community College: Strategies for Faculty Retention. Community College Journal of Research and Practice. 28(7): 593-607.

[27] Elashmawi, F., and Harris, P. R. 1993. Multicultural Management: New Skills for Global Success. Houston: Gulf Publishing Co. Expatriate. Journal of Management Inquiry. 8(3): 246-56. Faculty Satisfaction. Research in Higher Education. 46(7): 803-830. Foreigners. New Straits Times.

[28] Hammersley, M. 1993. What is Social Research? Principles of Social and Educational Research Book, Block 1. Milton Keynes, The Open University

[29] Hassan, A. and Chandaran, S. 2005. Quality of Supervisor-Subordinate Relationship and Work Outcome: Organizational Justice as Mediator. IIUM Journal of Economic and Management. 13(1): 33-52.

[30] Hechanova, R., Beehr, T. A., and Christiansen, N. D. 2003. Antecedents and Consequences of Employees' Adjustment to Overseas Assignment: A Meta Analytic Review. Applied Psychology: An International Review. 52(2): 213-236. Retrieved from Academic Search Premier database.

[31] Hofstede, G. 1980. Culture's Consequences: International Differences In Work-Related Values. Beverly Hills, California: Sage Publication.

[32] Hofstede, G. 1991. Cultures and Organisations. McGraw-Hill, London.

[33] Homans, G. C. 1958. Social Behavior as Exchange. American Journal of Sociology. 63(6): 597-606.

[34] Hung-Wen, Lee. 2007. Factors that Influence Expatriate Failure: An Interview Study. International Journal of Management. 24/3: September 2007.

[35] Johnsrud, L. K and Heck, R. H. 1994. A University's Faculty: Predicting Those Who Will Stay and Those Who Leave. Journal for Higher Education Management. 10(1): 71-84.

[36] Johnsrud, L. K. \& Rosser, V. J. 2002. Faculty Members' Morale and Their Intention To Leave. The Journal of Higher Education. 73(4): 518-542.

[37] Kogut, B. and Singh, H. 1988. The Effect of National Culture on the Choice of Entry Model. Journal of International Business Studies. 49: $411-432$.

[38] Lee, T. W. and Mowday, R. T. 1987. Voluntarily Leaving An Organization: An Empirical Investigate of Steer's and Mowday's Model of Turnover. Academy of Management Journal. 30: 721-743.

[39] Loi, R., Ngo, H. Y. and Foley, S. 2006. Linking Employees' Justice Perceptions to Organizational Commitment and Intention to Leave: the Mediating Role of Perceived Organizational Support. Journal of Occupational and Organizational Psychology. 79(1): 101-20.

[40] Lysgaard, S. 1955. Adjustment in a Foreign Society. Norwegian Fullbright Ggantees Visiting Theunited States, International Social Science Bulletin. 7: 45-51.

[41] Mager, D. K. 1999. The Graying Professoriate. Chronicle of Higher Education A18.

[42] Malaysia. 1999. Statistical Report Dated from 01/01/1998 to 31/12/1998. Kuala Lumpur: Immigration Department of Malaysia.

[43] Malaysia. 2000. Statistical Report Dated from 01/01/1999 to 31/12/1999. Kuala Lumpur: Immigration Department of Malaysia

[44] Mark Gabriel Fenton. 2010. A Study of Selection, Training, and Host Country Cultural Adaptation Experiences of Expatriate Faculty. Research from United States AASCU Universities.

[45] Matier, M. W. 1990. Retaining Faculty: A Tale of Two Campuses. Research in Higher Education. 31(1): 39-60.

[46] Mendenhall, M. and Oddou, G. 1991. Readings and Cases in International Human Resource Management. PWS-Kent Publishing Company, Boston, MA.
[47] Norman, M., Ambrose, S. A., \& Huston, T. A. 2006. Assessing and Addressing Faculty Morale: Cultivating Consciousness, Empathy, and Empowerment. The Review of Higher Education. 29(3): 347-379.

[48] Osland, J. S. 1990. The Hero's Adventure: The Overseas Experience of Expatriate Business People. Unpublished Ph.D., Case Western Reserve $\begin{array}{llll}\text { University. } & \text { Retrieved } & \text { September } & \text { 9, }\end{array}$ fromhttp://etd.ohiolink.edu/sendpdf.cgi/Osland\%20Jovce\%20Sautters. pdf7accnum=case 1054660024 perceivedadjustment of Japanese expatriates in the USA. International Journal of Human Resource Management. 13(8): 1224-1244. Retrieved from Business Source Complete database

[49] Piercy, F., Giddings, V., Allen, K., Dixon, B., Mezaros, P., and Joest, K. 2005. Improving Campus Climate to Support Faculty Diversity and Retention: A Pilot Program for New Faculty. Innovative Higher Education. 30(1): 53-66.

[50] Reynolds, A. A. 2010. The Academic Expatriate in the United Arab Emirates: A New Lens Through Which to View Expatriate Sociocultural Adjustment. Doctor Philosophy, Capella University, 2010

[51] Richardson, J. 2008. The Independent Expatriate: Academics abroad. Saarbrucken, Germany: VDM Verlag.

[52] Richardson, J., McBey, K., \& McKenna, S. 2005. Internationalizing Canada's Universities: Where Do International Faculty Fit In? In R. Trilokekar (Ed.). The Internationalization of Higher Education. Article provided by author, volume and issue number not available.

[53] Roscoe, J. T. 1975. Fundamental Research Statistics for the Behavioural Sciences. $2^{\text {nd }}$ edition. New York: Holt Rinehart \& Winston

[54] Saiful. 2012. retrieved from http://saifulbahri.com/Medical_education/Medical_Education_Notes_S em_2/SAMPLE_SIZE.pdf.

[55] Schermerhorn, J. R. 1999. Learning by Going? The Management Educator.

[56] Schoepp, K. W. 2010. Expatriate Faculty Retention in the Public Higher Education Institutions of the United Arab Emirates. Research from Graduate Division of Educational Research Calgary, Alberta.

[57] Searle, W., and Ward, C. 1990. The Prediction of Psychological and Sociocultural Adjustment During Cross-Cultural Transitions. International Journal of Intercultural Relations. 14: 449-464.

[58] Shaffer, M. A., and Harrison, D. A. 2001. Forgotten Partners of International Assignments: Development and Test of a Model of Spouse Adjustment. Journal of Applied Psychology. 86(2): 238-254.

[59] Shephard, P. 1996. Working with Malaysians - expatriates' and Malaysians' perspectives. In Asma Abdullah (Ed.), Understanding the Malaysian Workforce - Guidelines for Managers. Malaysian Institute of Management. 144-155.

[60] Shilling, M. 1993. Avoid Expatriate Culture Shock. HR Magazine. 38(7): 58-64.

[61] Sims, R., \& Schraeder, M. 2004. An Examination of Salient Factors Affecting Expatriate Culture Shock. Journal of Business Management. 10(1):73-87.

[62] Smart, J. C. 1990. A Causal Model of Faculty Turnover Intentions. Research in Higher Education. 31(5): 405-424.

[63] Stahl, G. K., \& Cagliari, P. 2005. The Effectiveness of Expatriate Coping Strategies: The Moderating Role of Cultural Distance, Position Level, and Time on the International Assignment. Journal of Applied Psychology. 90(4): 603-615.

[64] Takeuchi, R., Yun, S., and Russell, J. E. A. 2002. Antecedents and Consequences of the Perceived Adjustment of Japanese Expatriates in the USA. International Journal of Human Resource Management. 13(8): 1224-1244. Retrieved from Business Source Complete database.

[65] Tandogan, Z. G and Incirlioglu, E. O. 2004 Academics In Motion: Cultural Encapsulation and Feeling at Home. City \& Society. 16(1): $99-114$.

[66] Thompson, M. D. 2005. Organizational Climate Perception and Job Element Satisfaction: A Multi-Frame Application in a Higher Education Setting. E-Journal of Organizational Learning and Leadership, 4. Retrieved November 3, 2006, from http://www.weladinlearning.org/mt05.html.

[67] Tung, R. L. 1998. American expatriates abroad: From Neophytes to Cosmopolitans. Journal of World Business. 33(2): 125-144. Retrieved from Business Source Complete database.

[68] Usunier, J. 1998. Oral Pleasure and Expatriate Satisfaction: An Empirical Approach. International Business Review. 7: 89-110.

[69] Wan, Z., L. E. Leightley. 2006. Job Satisfaction and Workforce Demographics: A Longitudinal Study of the U.S. Forest Products Industry. Forest and Wildlife Research Center, Research Bulletin FP 362, Mississippi State University. 7.

[70] Ward, C. \& Rana-Deuba. 1999. Acculturation and Adaptation Revisited. Journal of Crosscultural Psychology. 30(4): 422-442.

[71] Ward, C., \& Kennedy, A. 1996. Before and after Cross-Cultural 
transition: a study of New Zealand volunteers on field assignments. In

Grad, H., Blanco, A., \& Georgas, J. (Eds.), Key Issues in Cross Cultural Psychology. 139-154. Lisse, The Netherlands: Swets \& Zeitlinger Publishers.

[72] Weiler, W. C. 1985. Why Do Faculty Members Leave a University?
Research in Higher Education. 23(3): 270-278.

[73] Williams, S., Pitre, R. and Zainuba, M. 2002. Justice And Organizational Citizenship Behavior Intentions: Fair Treatment Versus Fair Treatment. The Journal of Social Psychology. 142(1): 33-44. 